\title{
The International Association of Machinists, Pratt \& Whitney, and the Struggle for a Blue-Collar Future in Connecticut
}

\author{
ROBERT FORRANT
}

\section{INTRODUCTION}

Riding down Main Street in East Hartford, Connecticut toward the six smokestacks dominating the front of Pratt \& Whitney's mammoth aircraft engine factory, one cannot help noticing numerous artifacts associated with rapid industrial decline: empty and trash-strewn lots, boarded-up storefronts, and vacated triple-deckers, once homes for Pratt \& Whitney workers. A short drive away on the other side of the Connecticut River one can observe the dichotomies between East Hartford and downtown Hartford with its glittering insurance companies, banks, and the headquarters - known around Hartford as the "Gold Building" - of Pratt's parent, the United Technologies Corporation (UTC). The various social clubs, bars, and purveyors of fast food, ice cream, and fresh baked pies, that have served thousands of lunches and early suppers to members of the International Association of Machinists (IAM) are at risk.

Our mini-tour makes apparent the economic uncertainty and painful "pulling apart" of the social fabric in Connecticut's and the rest of the once-industrial northeast United States' older cities caused in large measure by the disappearance of well-paying manufacturing jobs. With over one million such jobs lost during the most recent US recession, including hundreds of machining jobs at Pratt \& Whitney, workers there rightly fear for their futures. The Union Hall for East Hartford's IAM Local 1746 sits directly opposite the main gates of the plant. Inside, local president Mike Stone observed "Well paying, secure jobs which both provided a career for thousands of hard-working people and their families, and supported hundreds of retail and service establishments across the state - jobs workers in the past were able to pass along to their children continue to disappear." This is why, he said "with 4,500 members in the four Pratt \& Whitney locals, job security needs to be the focus of everything we do". ${ }^{\mathrm{I}}$

The members of Local I 746 and the three other Pratt \& Whitney union

I. Interview with Mike Stone by author, March 200I; Hartford Courant (20 June 1993), p. B4. 
locals scattered across Connecticut were not supposed to be worrying quite so intently about their futures. After highly contentious I993 negotiations, the Connecticut legislature and the union gave tax concessions, wage cuts, and weakened seniority language to Pratt/UTC in return for the corporation's commitment to rebuild employment in the state. But, thereafter, Pratt workers clashed several times with UTC over its failure to live up to the bargain. Events culminated at the end of $200 \mathrm{I}$ in the first strike against the company since the I960s. ${ }^{2}$

At the December 200I strike deadline, Pratt \& Whitney's final contract offer contained a Io per cent pay increase and a $\$ 1,000$ signing bonus. However, the proposed agreement permitted management to move 500 East Hartford jobs out-of-state, with only a nebulous commitment to bring in new work. After absorbing thousands of lost jobs in the 1980 s and I990s - Local I746 had over 9,000 members in I 983 and barely 2,500 on the strike's eve - at I 2.0I a.m. on 3 December $200 \mathrm{I}$ unionists established their boisterous picket lines. Despite the threatening economic climate unionists stood out, opposed to further job erosion. ${ }^{3}$

Before the strike vote, Gary Allen, the IAM's national aerospace coordinator, told several thousand cheering workers: "This is your defining moment as a union. You've got to send a message." And East Hartford local president Mike Stone added: "We can either die on the vine or fight to grow jobs in the state of Connecticut. Nothing is won without sacrifice. It is our time to sacrifice." On the picket line several hours later, I5-year Pratt worker Greg Adorno shared similar sentiments noting "What's the point of giving somebody a io per cent raise if they're not going to be here to benefit from it?" For James Parent, the directing business agent for IAM District 9I and its chief negotiator, the issues were clear: "We were at a point at the end of negotiations where we were close. It's not an issue of money. It's an issue of whether the jobs are going to be

2. For discussions of plant closings and community dislocation see Robert Forrant, "Neither a Sleepy Village nor a Coarse Factory Town': Skill in the Greater Springfield Massachusetts Industrial Economy 1800-1990", Journal of Industrial History, 4 (200I), pp. 24-47; JoAnn Wypijewski, "GE Brings Bad Things to Life", The Nation (I2 February 200I), pp. I 8-23; Jefferson Cowie, Capital Moves: RCA's 70-Year Quest For Cheap Labor (Ithaca, NY, 2000); William A. Adler, Mollie's Job: A Story of Life and Work on the Global Assembly Line (New York, 2000); Kathryn M. Dudley, The End of the Line: Lost Jobs, New Lives in Postindustrial America (Chicago, IL, 1994). For community studies of de-industrialization, Gordon Clark, Unions and Communities Under Siege: American Communities and the Crisis of Organized Labor (New York, 1989); June C. Nash, From Tank Town to High Tech: The Clash of Community and Industrial Cycles (Albany, NY, I989); Roger Keil, Los Angeles: Globalization, Urbanization and Social Struggles (New York, 1998); Doreen Massey and Richard Meegan, The Anatomy of Job Loss: The How, Why and Where of Employment Decline (London, 1982).

3. Daniel Altman, "Nation's Unemployment Rate Rises to $5.8 \%$ ", New York Times ( 5 January 2002), p. Bi; Reed Abelson, "AT Plans to Lay Off 5,000 Workers", ibid.; Sue Kirchhoff, "US jobless rate reaches 5.8\%", Boston Globe (5 January 2002), p. Ci; David Leonhardt, "The Rust Belt With a Drawl", New York Times (I 3 November 200I), p. Ci. 
here. What good is a good package if you don't have a job?"4 The IAM's fight for job security in the face of de-industrialization and capital flight is an important part of the larger story about the globalizing economy's impact on industrial workers and their communities.

\section{THE CONNECTICUT ECONOMY RESTRUCTURES: ANY ROOM FOR BLUE-COLLAR WORKERS?}

\section{Overview}

Less than fifty years ago, the United States accounted for close to half of global manufacturing output. After 1945, war-induced prosperity and increasing productivity coupled with the benefits of Keynesian fiscal and monetary policies contributed to rising living standards for many workers. Gross national product expanded dramatically, from \$2 I 3 billion in 1945 to more than \$500 billion in I960 and \$I trillion in 1970. Connecticut's capital city, Hartford, sat at the center of the 200-mile-long Connecticut River valley running between Bridgeport, Connecticut and Springfield, Vermont. For much of the nineteenth and twentieth centuries the valley's firms and its machinists and metalworkers related to the rest of the country and the world as an innovative and powerful manufacturing center. ${ }^{5}$ The region's diverse manufacturing base was secured early in the nineteenth century when Springfield, Massachusetts (twenty-five miles north of Hartford) became the site for an important federal armory. The armory had functioned as the hub of a flourishing industrial district, with Springfield and Hartford enjoying a comparative technological advantage over many other regions of the country due to the diffusion of manufacturing techniques such as the utilization of gages, fixtures, jigs, and dies and the availability of large numbers of skilled metalworkers. ${ }^{6}$ Early in the twentieth century, Massachusetts, Connecticut, and Vermont

4. Barbara Nagy, "Union Votes to Strike at Pratt", Hartford Courant (3 December 200I), p. I; John Moran and Barbara Nagy, "Job Security the Issue for Pratt Strikers", Hartford Courant (4 December 200I), p. I. For a look at what another union is attempting to do with a giant US corporation see Douglas Meyer, "Building Union Power in the Global Economy: A Case Study of the Coordinated Bargaining Committee of General Electric Unions”, Labor Studies Journal, 26 (200I), pp. 60-7I.

5. James A. Henretta, David Brody, and Lynn Dumenil, America: A Concise History (New York, 1999), ch. 29, pp. 779-805, 780. I rely in this section on material from Suzanne Konzelmann and Robert Forrant, "Creative Work Systems in Destructive Markets", in Brendan Burchell, Simon Deakin, Jonathan Michie, and Jill Rubery (eds) Business Organization and Productive Systems (London, forthcoming 2002).

6. Nathan Rosenberg (ed.), The American System of Manufactures: The Report of the Committee on the Machinery of the United States I855 and the Special Reports of George Wallis and Joseph Whitworth (Edinburgh, 1969). For pre-Civil-War industrialization in New England see François Weil, "Capitalism and Industrialization in New England, I 8 I 5-1845", Journal of American History, 84 (1998), pp. I334-1354. See also Felicia Deyrup's Arms 
ranked second, fourth, and ninth respectively in the US for machine-tool sales. A plentiful pool of skilled machinists and engineers, a well-practiced reciprocal relationship among machine-tool builders and their customers, and the presence of hundreds of tool-and-die shops enhanced the valley's industrial competitiveness. ${ }^{7}$

\section{Declining unions - declining standards of living}

This premier position was eroded during the I970s and the I980s as Japan, continental Europe, and developing Asian nations emerged to challenge US pre-eminence in autos, steel, major household appliances, and consumer electronics. Job loss intensified during the 1973-1975 recession and spiked between I 979 and 1983 when over 2 million jobs (almost I 6 per cent of the national total) in several highly unionized durable goods sectors were lost as corporations shifted large segments of their manufacturing activities overseas. Among the Fortune 500's largest manufacturers employment fell to I 2.4 million from I 5.9 million between I980 and I 990. General Motors, Ford, Boeing, GE, and UTC collectively eliminated 230,000 jobs from I 990 to I 995 .

Globalization increased the international labor pool and made capital and work more mobile. Firms globalized corporate assets and expanded their direct foreign investment in factories, office buildings, office equipment, and machine tools. Whereas in 1965 this investment amounted to less than \$50 billion, it reached \$ 24 billion in 1975, surpassed \$2 I3 billion in 1980 and climbed to \$610.I billion in I994. Even in those industries like jet engines where US-based producers had been successful at maintaining market share in international competition, enterprise success did not necessarily serve to insulate workers from the effects of corporate restructuring and job loss. ${ }^{8}$

Makers of the Connecticut Valley (Northampton, MA, I948). For Springfield's industrial growth and decline Robert Forrant, "Roots of Connecticut River Valley Deindustrialization: The Springfield American Bosch Plant 1940-1975", Historical Journal of Massachusetts, (Winter 2003, forthcoming).

7. The Fourteenth United States Census ( 1920) reported that 25 per cent of the nation's machine tools were shipped from Massachusetts, Connecticut, and Rhode Island, and approximately 20 per cent of the country's machine tool firms employing more than roo workers were found along the Connecticut River; Deyrup, Arms Makers, p. 66; Frisch, Town into City, p. I 5.

8. By 1996 about three-quarters of all employed Americans worked in service industries, up from two-thirds in 1979. For a discussion of these trends see Stephen Herzenberg, J. Alic, J. and H. Wial, New Rules for a New Economy: Employment and Opportunity in Postindustrial America (Ithaca, NY, I998); Kim Moody, Workers in a Lean World: Unions in the International Economy (New York, 1997); Barry Bluestone and Bennet Harrison, Lean and Mean: The Changing Landscape of Corporate Power in the Age of Flexibility (New York, I994); Robert Forrant, "Between a Rock and a Hard Place: US Industrial Unions and the Lean, Mean Global Economy: Unions on the Shop Floor as the Next Century Approaches", Cambridge Journal of Economics, 24 (2000), pp. 75 I-769. 
Unionized workers felt the full negative force of this corporate and labor market restructuring. Overall, one in three American workers belonged to a union in the mid-r950s compared to one in seven in I999. The percentage of unionized manufacturing jobs declined from almost 50 per cent in I 970 to approximately Io per cent in the mid-I990s. Yet over this 25 -year period very little concerted, collective action on the part of trade unions to oppose this massive job loss took place. As organized labor's ranks thinned and manufacturing declined, many communities scrambled to save what jobs they could by offering corporations financial inducement to stay or move into their town. While seeking such "tribute", companies routinely threatened work removal to quash organizing campaigns. And during most rounds of collective bargaining in the I980s and I990s corporations demanded and often received wage and benefits concessions from workers. ${ }^{9}$

A consequence of the disappearance of well-paying manufacturing jobs has been wage depression, declining household wealth, and increasing income inequality. For nearly 20 per cent of American households, debts exceed assets, meaning that net worth is zero or negative. Between 1987 and 1996 average employee compensation in the US grew just I.I per cent, compared with 4 per cent between 1977 and I986. For most workers, real wages are below their 1973 levels. In aggregate terms, labor's share of the national income dropped from 66.2 per cent in 1970 to 59 per cent in I 995 . In 1998 the International Labour Organization summarized these trends: "Recently, while many trade unions have been pressing for reduced work time, guarantees of employment security and measures to combat unemployment, some employers have been seeking to modify many of the hard-won social protection measures in an effort to make labour markets less rigid." ${ }^{\circ}$

On the surface, current developments in manufacturing seem inconsistent with US macro-economic and stock-market conditions during the I990s because they coincide with one of the longest macro-economic

9. For union membership see L. Belsey, "Labor's Place in the New Economy", Christian Science Monitor (27 March 2000), p. I. For a discussion of the global aspects of capital flight, see William Greider, One World Ready or Not: The Manic Logic of Global Capitalism (New York, 1997), esp. chs 5 and 7; International Labour Organization [hereafter, ILO], The Impact of Flexible Labour Market Arrangements in the Machinery, Electrical and Electronic Industries (Geneva, 1997); William Lazonick and Mary O’Sullivan (eds), Corporate Governance and Sustainable Prosperity (New York, 2002); J. Tagliabue, "Buona Notte, Guten Tag: Europe's New Workdays", New York Times (20 October 1997), p. Di; L. Uchitelle, "Global Good Times Meet the Global Glut”, New York Times (I6 November 1997), p. Di; Teresa Hayter and David Harvey (eds), The Factory and the City: The Story of the Cowley Automobile Works in Oxford (London, 1993); Andre Lipietz, Mirages and Miracles: The Crisis of Global Fordism (London, 1987).

Io. ILO, The Impact of Flexible Labour, p. I; Frank Hansen, "Compensation in the New Economy”, Compensation and Benefits Review, 30 (1998), pp. 7-15. 
expansions in US postwar history, with unemployment and inflation at record low levels. In 1999, unemployment was 4.2 per cent while inflation was 2.2 per cent. They also coincide with the longest US stock market boom in history, with yields on corporate stock significantly above their depressed I970s levels. Since I990, productivity has risen 7 per cent, due to enormous gains in certain sectors. By the mid I990s, corporate profit rates were back to the level they had reached at the peak of the post World-WarII boom; in 1997, corporate profits rose to II.8 per cent of revenues, up from II.5 per cent in 1996, representing their highest level since I959, when the Commerce Department first began tracking this data. ${ }^{I I}$

\section{General Electric: "model behavior"?}

Pratt \& Whitney and General Electric (GE) have been the global market leaders in supplying engines to power aircraft of all types since the end of the Second World War. In jet-engine manufacturing (as in machine tools and steel), the employment picture was gloomy for most of the i 990 s. Both the blue-collar and the white-collar workforces have shrunk by about 35 per cent since I988. While much of the downsizing in the early part of the decade could be attributed to declining defense orders, the recovery of the aircraft market by the mid-I990s did little to restore employment levels in the jet-engine sector. Employment in the industry remains stuck at a level fully one-third below r 990 employment levels while inflation-adjusted average hourly earnings remained flat throughout. To understand how deindustrialization occurred in many older manufacturing cities in the US the corporate behavior of GE is worth considering, especially since it is Pratt's most important competitor. ${ }^{\mathrm{I} 2}$

GE's search for cheaper production facilities places continuous pressure on Pratt to follow suit. Starting in the late i950s, GE moved to parallel production, the practice of building several production facilities capable of handling the same work. By so doing, it could extract union concessions and reduce the threat of strikes under the possible threat of work removal. More recently GE has implemented shopfloor programs designed to boost productivity and improve quality. In the late I980s, GE began to implement continuous improvement strategies called the "GE Workout" in its aircraft engine plants. This program was designed to accomplish four

I I. United States Department of Commerce, Bureau of Labor Statistics (2000); Mary O'Sullivan, "Shareholder Value, Financial Theory and Economic Performance", paper presented at the 52nd Annual Meeting of the Industrial Relations Research Association, Boston, 2000; Hansen, "Compensation in the New Economy".

I 2. This analysis borrows heavily from the work of Beth Almeida. See in particular "Good Jobs Flying Away: The US Jet Engine Industry", in Lazonick and O'Sullivan, Corporate Governance and Sustainable Prosperity, pp. I04-I40. 
things: establish trust on the factory floor between workers and managers; empower employees to make production improvement suggestions; eliminate unnecessary work; and establish a new shopfloor paradigm of boundaryless work. At the same time, GE sought to change the labor agreement to eliminate job classifications and broaden the tasks workers were expected to perform. Employees were told to welcome the freedom that boundaryless work offered and "to take advantage of it by using their minds creatively to figure out how to improve the company's operations". GE's Evendale, Ohio, aircraft-engine facility was the first to respond. When workers there refused to ratify contract changes, the company shifted work to other facilities. Forty per cent of all parts made at Evendale were removed and 3,900 workers lost their jobs. ${ }^{13}$ GE then turned to its workforce in Lynn, seeking the same contract concessions, only to be similarly rebuffed. Eventually the Lynn local agreed to contract modifications and the introduction of GE's multiskilling program. ${ }^{\mathrm{I} 4}$

Parallel production and continuous improvement have been richly rewarding for GE: in 1998 the company registered \$1.7 billion in operating profits on \$ 10 billion in sales, translating into an operating margin of $\mathrm{I} 7 \mathrm{per}$ cent. Late in 1999, GE flexed its global muscles once more to move well beyond parallel domestic plants, for in a move that will further the deindustrialization of the northeast United States the company launched its "Globalization and Supplier Migration" strategy. Its components suppliers were ordered to achieve io to I4 per cent annual cost reductions, savings that could be realized only by shifting work to countries with lower cost structures. GE stated: "Migrate or be out of business; not a matter of if, just when. We expect you to move and move quickly." A carrot was offered: "We sincerely want you to participate and will help, but if you don't we will move on without you." The benefits for a move to Mexico, according to GE, included average daily wage rates of $\$ 6.00$, friendly unions, and the promise of long-term low labor costs.

According to IAM economist Beth Almeida, what is taking place "should serve as a warning to those who would maintain that the US will

I3. Robert Slater, The GE Way Handbook (New York, 2000), p. 50; Konzelmann and Forrant, "Creative Work Systems". Employment at Evendale was close to 20,000 in I988; at the end of I 994 only 8,000 workers remained.

I4. For example, former GE engineer Oswald Jones cites GE manager Charles Pieper, who supervised several plant reorganizations in Europe, as he describes how workers relate to participation programs: "I have never see a group of people who are not interested. Never. Never. Never. Whether you are Chinese, Hungarian, Japanese, Swedish, people love to go and make their workplace better". While Pieper was president of GE Lighting Europe, passionately committed workers saw factories drop from 24 to I 2 and employment from 24,000 to I 3,000. Jones concludes "It is hardly surprising that workers regard GE managerial initiatives to make the workplace better with considerable skepticism." Oswald Jones, "Changing the Balance? Taylorism, TQM, and Work Organisation", New Technology, Work and Employment, I 2 (1997), pp. I3-24, 20-22. 
always win out in the high-tech manufacturing race. The idea that only poor-quality jobs in low-tech industries are being lost to competitor nations is refuted by the experience of aerospace workers". ${ }^{\text {is }}$ In the context of these disturbing global trends, what happens at Pratt will have wide ramifications, for should the company flee Connecticut or squeeze its hundreds of suppliers in the same way that GE is, it will mark the nadir for large-firm metalworking unions in the entire Connecticut River Valley, once one of world's pre-eminent industrial regions. ${ }^{16}$

\section{De-industrialization and economic restructuring in Connecticut}

In Connecticut 4 out of Io manufacturing jobs were lost between 1980 and 2000, with drastic cuts at Pratt \& Whitney contributing to the bloodletting. (See Table I for the employment structure of the Connecticut economy.) In I 999 there were 18,700 fewer jobs in primary metals $(-66.6$ per cent), 37,300 fewer jobs in industrial machinery ( -54.2 per cent), and 48,500 fewer jobs in transportation equipment $(-53$ per cent) than in I $967 .{ }^{17}$ Connecticut netted roughly I I 3,000 new jobs from I 985 to 2000. But employment gains were by-and-large in low-paying services and retail trade - health care, copy centers, temporary help agencies and entertainment. (See Tables 2 and 3 for state employment data.) Finance, insurance, and real estate (FIRE) only added I0,000 jobs over the I 5 -year period, this in a state that claims it is the insurance capital of the United States. From the third quarter of 1999 to the third quarter of 2000 , manufacturing lost 3,700 jobs and services and retail trade added I4,000 jobs in Connecticut. But with the exception of FIRE - average weekly wage \$I,359 - average wages in the growth sectors trailed manufacturing wages. In 2000, the average weekly manufacturing wage was \$I,II7 compared to \$7I for services and $\$ 427$ for retail trade. It should be noted that the average wage for Connecticut aerospace workers was about is per cent higher than the statewide average manufacturing wage. ${ }^{18}$

I 5. Aaron Bernstein, "Welch's March to the South”, Business Week (6 December 1999), p. 74; J. Millman, "GE boosts Mexican Output as Labor Talks in US Near", The Wall Street Journal (5 January 2000), p. 8; Almeida, "Good Jobs Flying Away", p. Io6.

I6. R. Mokhiber and R. Weissman, "GE: Every Plant on a Barge", see: www.corporatepredators.org. See also Greider, One World Ready or Not; Forrant, "Between a Rock"; Kapstein, "Workers and the World Economy"; ILO, The Impact of Flexible Labour. 17. Wage data comes from the Connecticut Department of Labor web site, www.ct.dol.ct/us/ $1 \mathrm{mi} / 20299 \mathrm{ct} . \mathrm{htm}$; 1999 is the last year reported.

18. Connecticut Economic Digest (April 2001), p. 7; ibid., (August 2001), p. 5; ibid., (September 200I), p. 2. Across Connecticut, the fastest growing occupations include eating and drinking establishments, cleaning and lawn care services, catalog and mail-order houses, and household audio and visual equipment sales. None of these occupations makes any use of the precision manufacturing skills held by Pratt \& Whitney workers and none of these occupations pays a remotely similar wage. 
Table I. Connecticut manufacturing establishments and employment, I962-I997.

\begin{tabular}{lccc}
\hline Year & Establishments & All employees & Production workers \\
\hline 1962 & 5,697 & 419,400 & 294,000 \\
1967 & 5,829 & 477,700 & 329,900 \\
1972 & 5,836 & 399,300 & 258,200 \\
1977 & 6,485 & 412,100 & 255,300 \\
1982 & 6,693 & 424,400 & 245,000 \\
1987 & 6,747 & 388,900 & 216,500 \\
1992 & 6,282 & 320,800 & 171,000 \\
1997 & 5,911 & 263,000 & - \\
\hline
\end{tabular}

Source: United States Department of Commerce Manufacturing Census conducted every five years.

Table 2. Structure of Connecticut economy by employment categories.

\begin{tabular}{lrrrc}
\hline & \multicolumn{1}{c}{1985} & \multicolumn{1}{c}{1999} & Job change & \% change \\
\hline Total employment & $1,558,100$ & $1,671,500$ & 113,400 & 7 \\
Manufacturing & 408,000 & 269,200 & $-138,800$ & -34 \\
Transportation and & 68,300 & 78,200 & 9,900 & 15 \\
public utilities & & & & \\
Services & 349,600 & 526,600 & 177,000 & 50 \\
Finance, insurance, & 130,400 & 140,700 & 10,300 & 8 \\
real estate & & & & 4 \\
Trade (wholesale/ & 346,000 & 359,500 & 13,500 & 4 \\
retail) & & & & -7 \\
Construction & 65,400 & 60,900 & $-4,500$ & 25 \\
Government & 188,800 & 235,600 & 46,800 & -50 \\
Mining & 1,600 & 800 & -800 & \\
\hline
\end{tabular}

Source: Connecticut Department of Labor; www.ctdol.state.ct.us/lmi.

Table 3. Connecticut employment by percentages 1985 and 1999.

\begin{tabular}{lrr}
\hline & 1985 & 1999 \\
\hline Manufacturing & 26.2 & 16.1 \\
Transportation and public utilities & 4.3 & 4.6 \\
Services & 22.4 & 31.5 \\
Finance, insurance, real estate & 8.3 & 8.4 \\
Wholesale and retail trade & 22.2 & 21.5 \\
Construction & 4.1 & 3.6 \\
Government & 12.1 & 14.0 \\
Mining & 1.0 & 1.0 \\
\hline
\end{tabular}

Source: Connecticut Department of Labor; www.ctdol.state.ct.us/lmi. 
In their research on de-industrialization, Doreen Massey and Richard Meegan make the point the parties to the process - labor and capital - do not suffer the same outcomes. This is the case in the US, for corporate profits had returned to peak post-World-War-II levels by the mid-I990s, yet in Connecticut - home to the corporate headquarters of several leading global corporations - median real family income had fallen i4 per cent from I990 to 2000. ${ }^{19}$ By the mid-I990s, when adjusted for inflation, US workers' median income was 5 per cent lower than in the late I970s and household wealth was more concentrated than ever before. The top 5 per cent of households (those making $\$$ I 33,000 or more) controlled 2I.4 per cent of all income while the bottom 60 per cent controlled 27.6 per cent. This represents a reversal of the 20 years after the Second World War, when as the country's industrial base expanded there had been a steady decline in family income inequality. ${ }^{20}$

In addition, while many central cities in the US added residents and jobs in the I990s, there was a Is per cent drop in population and no net employment gains in Connecticut's capital city, Hartford, over the Io-year period. This stagnation was "reflected to a lesser degree in all of Connecticut's large cities with the exception of Stamford in Fairfield County", resulting in a "widening economic and racial segregation in Connecticut, which is the richest state in the country". ${ }^{21}$ Among I44 metropolitan areas examined by the federal government, Hartford finished I Ioth in high-tech employment growth. David Harvey and Erik Swyngedouw documented a similar phenomenon in their discussion of massive layoffs at a Rover assembly plant in Cowley, an industrial suburb of Oxford. There, restructuring

[...] meant not only the loss of many of those secure jobs which secured community affluence for many, but a transition in the qualities of the jobs that remained (through speed-up, deskilling, and the like) so that the difference

I9. In 1997 corporate profits were I I.8 per cent of revenues, representing their highest level since 1959, when the Commerce Department first began tracking this data. Massey and Meegan, The Anatomy of Job Loss, p. vii; Andrew Sum, The Story of Household Incomes in the I990s (Boston, MA, 200I). The report can be located at www.massinc.org/publications/reports.

20. Chuck Collins, B. Leondar-Wright, and Holly Sklar, Shifting Fortunes: The Perils of the Growing American Wealth Gap (Boston, MA, I999); Hansen, "Compensation in the New Economy"; David Weinberg, "A Brief Look at Postwar US Income Inequality", Current Population Reports (Washington DC, I996), pp. 60-9I.

21. David M. Herszenhorn, "Behind Census Numbers In a Declining Hartford", New York Times (22 March 200I), p. A22; Janny Scott, "Connecticut Population Shifts Toward New York," New York Times (20 March 200I), p. I. MassInc reports that for seven of the nine northeast states, "median real incomes were below those of 1989, with Connecticut, Massachusetts, New Hampshire, and New York faring the worst in the region". Connecticut median household income in constant 1999 dollars fell to $\$ 49,267$, from $\$ 56,916$ in 1989 , the largest drop among the ten northeast states (www.massinc.org). 
between the marginalized and the employed became less rather than more marked. ${ }^{22}$

For Pratt workers the downward trends produced a good deal of economic insecurity. Turret lathe operator and IAM Executive Board member, Ted Durkin, noted that while there are some jobs available paying decent wages they require considerable training. "I'm 45 and lots of other workers are older. Not too many folks will want to start all over again and go back to school." The jobs that are available absent education are at the Home Depot or at small-job shops, but for a lot less money. Machinist and union shop committee member, John Cloutier, added that years ago "you could get your foot in the door here [Pratt], project into the future, and see yourself with a steady job for thirty or more years; but no more". He wondered "How do you sign for a mortgage, buy a car, save for your kid's college when your employment future is so insecure?" 23

\section{UNITED TECHNOLOGIES CORPORATION: GOOD JOBS FLYING AWA Y?}

\section{UTC, Pratt \& Whitney, and the Connecticut economy}

Pratt \& Whitney is a major business segment of UTC and employs roughly i 2,000 people in Connecticut, and 30,000 worldwide. With nearly 2,000 locations in 220 countries, in 200I UTC ranked 57th among US corporations and 125 th in the world. UTC's global workforce totaled I 50,000 in 2000, down 25 per cent from I 990. As a result of the transfer of capital commitments abroad, 54 per cent of all employees are outside the US. UTC's other major business segments are: Flight Systems, which includes Hamilton Sundstrand and Sikorsky, producer of such things as engine controls, environmental control systems, aircraft propellers, and helicopters; Carrier Air Conditioner, the world's largest manufacturer of heating, ventilating, and air-conditioning systems; and Otis Elevator, the world's leader in the manufacture of elevators, escalators, and automated people movers. ${ }^{24}$

22. David Harvey and Erik Swyngedouw, "Industrial Restructuring, Community Disempowerment and Grass-Roots Resistance", in Hayter and Harvey, The Factory and The City, pp. I I-25, I6; United States Department of Housing and Urban Development, The State of the Cities 2000 (Washington DC, 2000).

23. Author interviews at the Pratt \& Whitney Local 1746 Union Hall in December 2000 and January and March 200I.

24. UTC, Annual Report 2000 (n.p., n.d.). The states are Arkansas, California, Connecticut, Georgia, Maine, Michigan, Minnesota, Oklahoma, and Texas. European and Asian joint ventures are in Dublin, Ireland, Tapei, Taiwan, Kiev, Ukraine, and Singapore. Hamilton Sundstrand, also in Connecticut, employs 17,000 people worldwide, with about 4,000 in Connecticut. Jet-engine manufacturing, overhaul, and repair operations are located in eight states and Puerto Rico, and there are international overhaul and repair operations in Canada, 
Pratt \& Whitney and its global competitor, General Electric, are world leaders in the manufacture of jet engines. A truly indigenous New England industry, i $28 \mathrm{New}$ England firms and 34,000 people built complex parts, components, subassemblies, and control systems for engines during I999; the majority of these firms were subcontractors to Lynn, Massachusettsbased General Electric and/or Pratt \& Whitney. This represented 28 per cent of total US aircraft engine manufacturing employment. ${ }^{25}$

Originally a machine tool builder, the Pratt \& Whitney Company was incorporated in Hartford in 1855 . It began to focus on aircraft engines in I929 and dynamic growth in the decades after the Second World War made Pratt \& Whitney the most important industrial employer in Connecticut. For fifty years, thousands of well-paid machinists at Pratt $\&$ Whitney built engines, created massive amounts of wealth for investors, and fueled the growth of hundreds of small- and medium-sized metalworking and precision manufacturing firms and retail and wholesale establishments across Connecticut and western Massachusetts. During the I950s and I960s Pratt \& Whitney established the wherewithal to produce globally; Pratt's manufacturing and engineering projects take place in nine states and several European and Asian countries. This has made it possible for Pratt to whipsaw unions, communities, and entire nations to exact concessions for jobs. ${ }^{26}$ As though playing a giant board game, Pratt constantly shifted work between Connecticut, Florida, and Maine, while at the same time participating in its numerous overseas manufacturing ventures. For the IAM in Connecticut - and for other industrial unions in the US where corporations availed themselves of an extended geography of production - these maneuvers served to weaken contractual seniority and job classification language and significantly reduced the threat of strikes. ${ }^{27}$

Highly profitable in the late I990s, UTC's investors and top managers were handsomely rewarded. In 200 I, Forbes placed UTC on its prestigious "platinum list" of 400 US corporations, noting that when compared to its aerospace and defense industry peers, "UTC had the second-best five-year average for return on capital (2 I per cent) and virtually tied for first place

China, UK, France, Germany, Ireland, Italy, Malaysia, the Netherlands, Russia, and Singapore. 25. I am indebted here to research being done by Beth Almeida, an economist with the International Association of Machinists in Washington DC. For the impact of General Electric's abandonment of Pittsfield, Massachusetts, see Max. H. Kirsch, In the Wake of the Giant: Multinational Restructuring and Uneven Development in a New England Community (Albany, NY, 1998). Kirsch notes that GE expanded during the I970s, adding 30,000 jobs abroad while decreasing domestic employment by 25,000 , see ibid., p.I3.

26. Robert Forrant, "Too Many Bends in the River: The Decline of the Connecticut River Valley Machine Tool Industry", Journal of Industrial History, 5 (2002, forthcoming).

27. Kapstein, "Workers and the World Economy"; Almeida, "Good Jobs Flying Away"; Jones, "Changing the Balance?"; Bryn Jones, Forging the Factory of the Future: Cybernation and Societal Institutions (Cambridge, 1997). 
in the five-year average for earnings per share growth (2I.9 per cent)". ${ }^{28}$ Its revenues of $\$ 26.6$ billion in 2000 were well above 1996 's $\$$ I 9.9 billion, and earnings per common share of $\$ 3.55$ in 2000 , compared favorably to \$1.74 in 1996. Pratt's 2000 operating profit of $\$ 1.2$ billion accounted for 35 per cent of UTC's \$3.4 billion total. The corporation's 2000 Year in Review proclaimed: "Investors do prize consistency, and UTC is committed to this above all. UTC's total share-owner return has compounded at an average 30 per cent annually since I994, well above market indices." Added the Review, "our \$I.8 billion in available cash flow also provides the engine of growth for acquisitions". Indeed, 35 acquisitions costing \$7.6 billion were completed in 1999-2000. But while profits escalated, workers rolled out the door; during I 999 alone UTC terminated I 5,000 employees from its global workforce - 4I firings a day for the calendar year - with Pratt \& Whitney worldwide absorbing 5,200 of the terminations. In the next section I discuss how Pratt/UTC achieved this profitability. ${ }^{29}$

\section{I993 concessionary bargaining}

Faced with the challenge of sharp defense spending cuts at the end of the Vietnam War, UTC diversified through the purchase of several companies, including Sikorsky Helicopter, Carrier Air Conditioning, Otis Elevators, and American Bosch. This, coupled with the late 1980 s boom in the commercial airline industry, produced strong years for Pratt \& Whitney. However, consolidation in the commercial airline sector and defense spending reductions after the destruction of the Berlin Wall caused the bottom to fall out of the jet-engine market and in the first quarter of I99I Pratt's earnings dropped 75 per cent. A new chief executive, Robert Daniell, arrived to slash manufacturing costs..$^{3 \circ}$ For Daniell, the solution was to squeeze \$I billion from costs; to achieve this 6,700 hourly and salaried jobs at Pratt's US facilities were to be eliminated. Losses continued across the corporation and in 1993 and Daniell introduced a more drastic 2-year restructuring program. UTC-wide, I4,000 jobs were to be eliminated -7 per cent of the global workforce - and Ioo facilities were to be closed. Even before these proposed cuts, the membership of the Pratt local in East Hartford had fallen under 6,000, from over 9,000 in $1983 .{ }^{3 \mathrm{I}}$

28. Howard Banks, "No More Yo-Yo", Forbes (i I January i999), pp. I30-I3 I; Claudia H. Deutsch, "Private Sector: Even His Soufflés Can't Relax", New York Times (ig November 2000), section 3, p. 2.

29. UTC, Year in Review (n.p., n.d.), pp. I, 8.

30. In the first quarter of 1991, earnings at Pratt dropped 75 per cent - less than half the predicted earnings. With UTC relying on Pratt for two-thirds of its operating income this was a particularly hard hit; Jonathan P. Hicks, "United Technologies Bumpy Ride", New York Times (i May i99i), p. Di.

3 I. George Judson, "Pratt \& Whitney Threatening to Shut Two Connecticut Plants", New York Times (is April I993), p. Ar. 
In 1993 George David - formerly head of Otis Elevators - became UTC Chief Operating Officer under Daniell, and Karl Krapek became President of Pratt \& Whitney. As 1993 began, the trio called for the termination of 10,000 Pratt employees worldwide. ${ }^{32}$ And in early spring they presented an ultimatum to the IAM and the state legislature: quickly generate \$30 million each in cost concessions or Pratt, "crown jewel of UTC and a pillar of Connecticut's economy for seventy years" would cease manufacturing in the state. Absent the concessions, 2,300 jobs were to be cut immediately, with the rest of the jobs phased out over several years. ${ }^{33}$ The parties understood that the future of jet-engine manufacturing in Connecticut was at stake. Bill Cibes, the state's budget director, commented "If you let 2,300 jobs leave Connecticut, that means the state is not competitive to retain the rest." 34 "Pratt \& Whitney is part of the business heritage of Connecticut", then Governor, Lowell Weicker, stated, "It's done well by Connecticut and its people. It belongs here. You've got to give up something in the tough times. We all do." 35

David and Krapek commanded the marathon bargaining sessions while deftly courting legislative delegations from Georgia and Maine - the sites of smaller Pratt \& Whitney plants - which offered the two men lucrative financial incentives for added jobs in their states. Hourly manufacturing costs in Connecticut, Krapek argued, were \$6-\$8 per worker higher compared to other states; getting these costs in line must be accomplished for Pratt to continue making aircraft engines in its birthplace. ${ }^{36}$ State officials believed that Pratt's cost figures were exaggerated, but they struggled to meet them, believing that Krapek's threat of a total shutdown was all too real. Unionists approached the talks with dim hopes, with many workers believing that the East Hartford plant's demise was imminent, regardless of the negotiations.

Ultimately, the legislature crafted incentives that included a research and development tax credit, loan guarantees for job training, and grants to train workers in Japanese-style lean production, and utility rate reductions. They also enacted policies that granted all Connecticut employers savings in workers' compensation insurance. For its part, the union agreed to a wage freeze, new productivity targets, and modifications to numerous work rules in exchange for vague company commitments to keep a minimum number of jobs in the state, limit their subcontracting, and halt

32. Robert Weisman, "Real Struggle for Pratt's Future Played Out in Private", Hartford Courant (26 December 1993), p. A.

33. Robert Weisman, "How Pratt Flexed its Muscle, and State, Union Relented", Hartford Courant (27 December 1993), p. Ar.

34. Weisman, "Real Struggle".

35. Weisman, "How Pratt Flexed".

36. Kirk Johnson, "By Pratt \& Whitney's Math, Connecticut Costs Too Much", New York Times (23 April 1993), p. Ar; Judson, "Pratt \& Whitney Threatening”. 
the movement of jobs to Maine and Georgia. After approving the concessions by a four-to-three margin, many machinists - even those voting for the concessions - expressed suspicions about Pratt's true intentions. But, in the words of one member, the feeling was that it was "better to preserve jobs and live to fight another day". Within a year UTC saw a financial payoff, in the form of a 20 per cent earnings increase on just a I per cent increase in sales; not surprisingly, workers were less fortunate. ${ }^{37}$

\section{The aftermath: Thanks - but not really}

After the concessions bargaining, a letter distributed to Pratt \& Whitney workers by Pratt boss, Karl Krapek, noted that "by agreeing to the plan, the workers had expressed faith in the future of our company". The company, he intoned, will undertake "significant redesign of our manufacturing, engineering and administrative processes" and keep work in the state. The Hartford Courant on Sunday 27 June 1993 contained a full-page advertisement in which management issued a very public thank you for granting them cost relief to the state's taxpayers and the union. Pratt credited the legislature for measures that now "make business more competitive" in Connecticut, praised the IAM for "convincing us to keep jobs in Connecticut" and applauded workers for their trust. "The spotlight now shines on Pratt \& Whitney to deliver on our promises", the ad trumpeted, and it concluded with an optimistic proclamation: "SOME DAY OUR BUSINESS WILL PICK UP AGAIN. THANKS TO YOU, IT WILL PICK UP IN CONNECTICUT". ${ }^{38}$ Yet the movement of work abroad intensified and the membership of IAM District 9I - which contained all of Connecticut's union locals representing UTC production and maintenance workers - fell from approximately I 3,000 in 1993 to less than 10,000 by 1999 . In 2000 , UTC announced its intention to trim an additional I 4,500 jobs corporation-wide over three years, with many cuts slated for Connecticut. ${ }^{39}$

\section{Worker responses - "We don't use logic with UTC"}

In March 200I Warren Occhialini, Ted Durkin, John Cloutier, and Mike Stone - Pratt workers and active union members - discussed I993's watershed events. They concurred that despite the corporation's insistence that they wanted an open style of industrial relations and an atmosphere of

37. Author interviews, $200 \mathrm{I}$.

38. Hartford Courant (20 June I993), p. B4; Thomas Lueck, "Jet-Engine Workers Accept Harsh Reality", New York Times (25 June I993), p. B6.

39. Lueck, "Jet-Engine Workers"; Tim Smart, "Global Mission”, Business Week (I May 1995), pp. $132-135$. 
trust, events since 1993 made this impossible. For despite the agreement and expansion promises, thousands more workers lost their jobs. "In the end the Pratt workforce is always smaller, despite assurances that this will not take place", noted Cloutier. Occhialini observed that the Local always loses jobs in the end because UTC believes that it can do whatever it wants. Cloutier noted that in I998, even after a signed agreement was reached between the union and the company to send 80,000 hours of work from East Hartford to North Berwick, Maine, with roo,000 hours of the Maine plant's work shifting to East Hartford. Work went to Maine, but the reverse trek never occurred..$^{\circ}$

In describing blue-collar attrition, Cloutier concluded that "two generations of workers are not on the shopfloor". Seventy-five per cent of Connecticut Pratt \& Whitney workers are over 45 and the average seniority in the plants is 22.I years. With layoffs and restructuring, there are virtually no machinists and machine operators in their twenties and thirties and no hiring is taking place. Cloutier noted that "serious, longterm education and training to upgrade the skills of shop floor workers does not take place. This would indicate there is a future here”. Durkin commented that Pratt has done such a poor job training people that they often rehire retirees at inflated salaries to train workers in shopfloor skills lost through early retirement and layoffs. Shaking his head, Durkin remarked: "We don't use logic with them when we discuss this kind of thing." Said Cloutier,

$[\ldots]$ the workforce is so lean that there is almost no way for new work to come into the shop because the existing workforce can not handle it. People are already working tremendous amounts of overtime because the plant is run so much on the margin in terms of needed workers. ${ }^{\mathrm{I}}$

For Cloutier and Durkin the restructuring has had little to do with workers being unable to perform the jobs. Since 1998 unionists have willingly participated in numerous efforts to reprocess how work is done to lower production costs and ostensibly save jobs. Yet, in a remarkably cynical maneuver, when job-redesign projects are concluded the work often "gets pulled out of the factory and shipped to an overseas business partner or a local job shop", Cloutier stated. Reacting in I 999 to proposed cuts at Pratt \& Whitney's North Haven, Middletown, and East Hartford

40. According to Cloutier, a I994 management survey of employee morale at Pratt was reported on in Business Week in 1995. While 78 per cent of employees reported pride in their work, fewer than half the workers felt any loyalty to the company; author interviews, 200I. The workshifting agreement is found in the 1998 collective bargaining agreement between District Lodge 9I and Pratt \& Whitney and reads in part: "approximately 2 I part numbers associated with LPT Blades will be moving from Maine to Connecticut. This work represents approximately 100,000 hours of work annually" (p. I29).

4I. Randy Barber and Robert Scott, Jobs on the Wing: Trading Away the Future of the US Aerospace Industry (Washington DC, I995); Smart, "Global Mission”. 
factories, IAM District 9I directing business representative James Parent expressed unionists' frustrations: “They don't realize that when they talk about a worker, it's not just one worker. They are talking about a whole family whose future is up in the air. They are talking about the tax base of North Haven, and all the surrounding communities where workers live." And in a January 200I interview, Parent reiterated his concern for keeping jobs in Connecticut and wondered where work that could generate a stable tax base was going to come from. "Why not grow jobs in Connecticut", asked Parent "instead of walking away from a workforce that averages 22+ years seniority?" 42

In their description of Rover's investment diversions, capital flight, and work relocation, Harvey and Swyngedouw posit that "innumerable companies have cashed in on local productive capacity for decades" only to determine that this capacity "is no longer useful to them, leaving behind thousands of lost jobs, a desolated local economy, and citizens, local governments as well as other community-based institutions (varying from trade unions to the churches) in confusion and disarray". It appeared likely to Parent that Pratt \& Whitney and UTC were set to cash-out in Connecticut. ${ }^{43}$

\section{THE TEN THOUSAND JOBS QUESTION}

\section{Flip burgers?}

In December 1998 IAM District 9I reached agreement on a 3-year contract with Pratt. At the time the company indicated that about I,000 additional jobs might be eliminated over the next three years due to what it termed "production scheduling problems". But unionists were assured that no rerun of the drastic cuts that took place in 1993 was anticipated. Company officials emphasized that Pratt \& Whitney was committed to Connecticut. Increased orders for very lucrative engine repairs and services were expected to boost jobs. But eight months later, without ever talking to the union, Krapek publicly announced that Pratt was going to relocate its engine repair and service work to Oklahoma and Texas and shutter a factory in Connecticut.

For the IAM, the unilateral declaration violated an important clause in

42. Author interviews, $200 \mathrm{I}$.

43. Harvey and Swyngedouw, "Industrial Restructuring", p. 20. Beth Almeida, "Linking Institutions of Governance and Industrial Outcomes: The Case of Global Aircraft Engine Manufacturing”, paper for the 52nd Annual Meeting of the Industrial Relations Research Association, Boston, 2000; author interview with James Parent. In 1998 Pratt took a majority interest in Singapore Airlines' engine shop, Hamilton acquired Ratier-Figeac in France, and Carrier commenced a joint venture with the Japanese manufacturer Toshiba. In 1999, Otis formed LG Otis Elevator Company in Korea with LG Electronics, Inc. UTC holds an 80 per cent equity interest in the new company (UTC Form Io-K, I998, I999). 
the 1998 labor agreement - Letter 22 Workplace Guarantees and Subcontracting - which bound Pratt to discuss with it any plans to remove work and to give the union an opportunity to match the cost savings that might accrue to the company from the move. The letter read in part:

The Company will make every effort to preserve the work presently and normally manufactured by employees covered by Article 2 of this Agreement. Therefore, it is not the intent of the Company to use subcontractors for the purpose of reducing or transferring work that is presently and normally manufactured by employees in the bargaining unit nor place such work in Maine or Georgia [...].44

As news of the North Haven closing spread, Gary Daly, age forty-eight with twenty years of service at Pratt, typified worker reactions. The company is "making record profits, and all they want is cheap labor, to bust the union", he noted. "We've got mortgages and families and are trying to send our kids to school. What are we going to do, flip burgers?" John Amato, who had worked at Pratt for just five years added, "I'm twenty-five and by the time I'm forty, there's going to be nothing left in Connecticut. They are going for cheap labor, that's all they want."45

\section{Federal courts intervene: contractual obligations violated}

Faced with the possible loss of their most important source of new work, on I6 September 1999 the IAM challenged the restructuring plan in federal court. Pratt's proposed cuts, argued the union, violated the 1998 labor agreement which obligated management to make reasonable efforts to keep work historically performed in Connecticut in the state at least until the contract expired in 200I. Stunning UTC, the United States District Court issued an injunction blocking the company's move until the case was heard. On I 8 February 2000, citing specific clauses in the collective bargaining agreement, Judge Janet Hall ruled that, "Pratt made, in fact, no effort to preserve the parts repair work presently and normally manufactured by bargaining unit employees.”

44. Agreement Between Aeronautical Industrial District Lodge 9I, IAMAW, AFL-CIO and Affiliated Locals and Pratt E Whitney (n.p., I998), p. I26; Barbara Nagy, "Pratt Braces For Upheaval", Hartford Courant (I3 August 1999), p. I; Dan Haar and Stacy Wong, "Shift: Connecticut's Gain Comes With Pain", ibid. The announced restructuring prompted an immediate 4.7 per cent increase (\$3.19) in United Technologies stock price. It was predicted that the combination of layoffs and job transfers could save the company \$ I 00 million to \$ I 50 million a year, starting in 200I. Matthew Lubanko, "Plan Wins Friends on Wall Street", Hartford Courant (I 3 August 1999), p. Di.

45. Robin Stansbury and Matthew Kauffman, "Local Businesses React", Hartford Courant (I 3 August 1999), p. Di; Patricia Seremet, "Shock Turns to Anger”, ibid. 
IAM members were jubilant when Judge Hall's determined that

Pratt's object was profit maximization, with no effort made to preserve the work in question. Its decision was driven by a desire solely to lower costs, in order to be more competitive and gain more business, all of which is rational and reasonable from a business perspective, absent Pratt's contractual obligation to the Union.

Pratt appealed the ruling in the United States Court of Appeals for the Second Circuit on I 2 May 2000, and on 26 October 2000 the Appeals Court upheld Judge Hall's decision. UTC was prevented from moving the work for the life of the contract. ${ }^{6}$

\section{Preparing for a fight: job loss analyzed}

Buoyed by their stunning court victory, District 9I's leaders started preparations for what they felt would be bruising contract negotiations in the Fall of 200I. Unionists expected that Pratt would seek the removal of the job-security language. Eager to head off a new round of concessionary bargaining and determined to preserve existing jobs, unionists established a broad-based jobs preservation campaign under the banner "Grow Jobs in Connecticut". One component of the effort was a report District 9I commissioned on de-industrialization in Connecticut since the I980s. As part of the report the Chicago-based Center for Labor \& Community Research (CLCR) prepared an analysis of the projected financial and job losses in Connecticut should UTC curtail its manufacturing across the state. The report became the centerpiece for an educational campaign with union members, the state legislature, church and community groups, and other trade unions across the state.

CLCR determined that curtailed manufacturing would mean an end to I I,300 Connecticut UTC jobs - 6, I00 production jobs and 5,200 support jobs. There would be a "ripple effect" cut of almost 21,000 additional jobs caused by the decreased wages and spending power; thus, total job losses would reach 32,400 . For each production job eliminated just over four additional jobs would be lost. Jobs in retail trade $(3,763)$, business services $(3,608)$, health services $(\mathrm{I}, 648)$, wholesale trade $(\mathrm{I}, 034)$, and construction $(\mathrm{I}, 024)$ would be the most severely impacted. Estimated costs for two years following the cessation of manufacturing included:47 (I) The loss of

46. Court Brief, United States District Court, District of Connecticut. Civil Action No. 3:99CV-I827 (JCH). Aeronautical Indus. Dist. Lodge 9I of the Int'l Ass'n of Machinists and Aerospace Workers, AFL-CIO Plaintiff, v. United Technologies Corp., Pratt \& Whitney Defendant (n.p., I 8 February 2000).

47. Ken Blum, Social Cost Analysis of the Impact of Closing UTC's Aircraft Engine and Parts Plants in Connecticut (Chicago, IL, 200I). For a discussion of employment multipliers and their calculation, see Dean Baker and Thea Lee, Employment Multipliers in the US Economy, Working 
\$304 million in local, state, and federal tax revenue along with an additional \$II9 million worth of expenditures to cover increased unemployment compensation. The two-year total cost to government would be $\$ 423$ million. (2) Two years after job loss - based on Connecticut wage figures a terminated production worker with a new job would earn just 76 per cent of his/her former income. Consideration was given to the fact that laid-off workers could receive severance wages and that many workers might receive some portion of their pension. (3) Based on March 200 I labor market information, it was estimated that 20 per cent of Pratt \& Whitney and Hamilton Sundstrand workers $(2,285$ people) would remain unemployed for at least 26 weeks and that 4.6 per cent ( 52 I people) would be unemployed after one year. Among the "ripple-effect" workers, an additional 699 people would be unemployed for at least one year. Thus, I,220 people would be unemployed for at least one year.

\section{The December 200 I strike}

After waging a broad-based community campaign, at I $2.0 \mathrm{I}$ a.m. on 3 December 200 I the first strike since I960 at Pratt \& Whitney began. The company's contract offer had included a Io per cent pay raise and a \$I,000 signing bonus, but, as anticipated, there were no job-security provisions. In fact, the proposed contract provided for the immediate removal of 500 East Hartford jobs out-of-state, with simply a nebulous promise to bring new work in. At the strike-vote meeting, Gary Allen, the IAM's national aerospace coordinator, told several thousand workers: "This is your defining moment as a union. You've got to send a message." Mike Stone, President of the East Hartford local added: "We can either die on the vine or fight to grow jobs in the state of Connecticut. Nothing is won without sacrifice. It is our time to sacrifice."

On the picket line I 5-year Pratt worker, Greg Adorno, asked "What's the point of giving somebody a Io per cent raise if they're not going to be here to benefit from it?” For James Parent, IAM District 9I's chief negotiator, the issue appeared cut and dried. "We were at a point at the end of negotiations where we were close. It's not an issue of money. It's an issue of whether the jobs are going to be here. What good is a good package if you don't have a job?" With 63 per cent of the membership lost in the

Paper No. 107 (Washington DC, I993). This study utilized an input-output model developed by the US Forest Service called Implan. The model produced multipliers showing sales, indirect business taxes, and jobs for all industries that produce inputs for the aircraft and missile engines and parts plants, and also industries producing goods and services consumed by UTC workers. The Center for Labor \& Community Research was founded in 1982 as the Midwest Center for Labor Research and has been involved in research and worker/community organizing campaigns to stop de-industrialization and preserve working-class communities. It can be reached at: www.clcr.org. 
past decade, Howard Haberern, with 34 years at Pratt, added "We're saying, leave the work in Connecticut. That's the crux of the whole thing." ${ }^{8} 8$

The IAM's national website reported,

This is a strike to protect America's defense industrial base. This is a strike to keep good paying jobs and decent retirements available to the people of Connecticut. We seek a contract that keeps Pratt \& Whitney successful and that keeps our members working. The company has illegally refused to provide information on subcontracted work inside the plants and on work they plan to send to outside vendors or overseas.

The union refused to abrogate the contract language it had so successfully used in federal court to block Pratt's earlier restructuring efforts. On the strike website, Gary Allen, head of IAM's aerospace division, remarked "The time has come to stand up and fight to save the best industrial jobs in Connecticut. IAM members and the people in our communities take this fight very seriously and we are committed to win." 49 Comments from the picket line reflected the strike's very high stakes. "I'm striking for the younger people", said fifty-four-year-old Mary Hurlburt, "They need a younger generation coming in to build these engines." 50

Ten days into the strike, on I 3 December 200I, workers ratified a new contract by a 75 per cent affirmative vote of the 4,000 votes cast. Pratt's prestrike wage offer remained unchanged. However, in an extremely important victory, Pratt agreed in writing to produce a new engine in Connecticut and work in the state remained subject to the court-tested Workplace Guarantee contract language. As a symbol of their commitment to "Grow Connecticut", Pratt agreed to start their very first joint Union/Company Apprenticeship Program. Finally, the company agreed to participate in the High Performance Work Organization training program at the IAM's New Technology Center. ${ }^{5 \mathrm{I}}$

\section{CLOSING THOUGHTS}

At the turn of the new millennium, global market pressures and shortproduct life cycles have forced the corporate officers of many firms to consider worker intellect an asset, not a liability. But, as the evidence in this section demonstrates, in the drive to maximize production and

48. Barbara Nagy, "Union Votes to Strike at Pratt", Hartford Courant (3 December 200I), p. I; John Moran and Barbara Nagy, "Job Security the Issue for Pratt Strikers", Hartford Courant (4 December 200I), p. I.

49. www.goiam.org/news.

50. Barbara Nagy, "Pratt Negotiations May Resume Soon", Hartford Courant (s December 200I), p. I.

5. Barbara Nagy and John Moran, "Strike is Over at Pratt", Hartford Courant (I4 December 200I), p. I. 
increase shareholder value, worker empowerment and team building still play second violin to the first chair occupied by output demand and "line speed-up". The delicate underpinnings of plant-level trust are threatened by the wherewithal of owners to arbitrarily shift production to gain even the slightest competitive advantages. Workers and their unions are thus squeezed between a rock and a hard place: they are condemned as backward thinkers should they refuse to consider management-proposed work changes that might give their plant a chance to prosper, yet they are equally doomed when they accede only to have managers "pick their brains" and transfer the work to plants in less expensive parts of the world, as occurred at Pratt \& Whitney.

The aircraft-engine and engine-parts and components industry reflects several disturbing trends for workers and communities that mirror the socioeconomic downturns faced by defense workers in the US tossed out of work from 1987 to 1997. In an examination of what happened to the close to one million defense-related manufacturing jobs lost during these years, Ann Markusen and Laura Powers concluded that "a majority of workers did not, on average, experience rapid re-employment at wages comparable or better" than their lost jobs. A sizable minority experienced a drop in earnings of 50 per cent or more, which suggests that "many defense workers did not become re-employed in jobs that capitalized on their existing skills". With the wherewithal to manufacture around the globe, Pratt and GE continues shrewdly to play off workers from different unions, communities, and nations for "sweetheart" financial deals in return for jobs.52 And as jobs exited Connecticut before the December 200I strike and economic uncertainty intensified, UTC's CEO George David was handsomely rewarded for the corporation's "excellent financial results and long-term strategic accomplishments" with a salary and stock bonuses which topped \$1 8 million. ${ }^{53}$

Over the years the state government and municipal governments have done little to protect the remainder of the state's manufacturing jobs. In the late I980s and early I990s, as manufacturers exited Connecticut and Massachusetts, the mayors of Hartford and Springfield engaged in a war of newspaper advertisements, each one trying to entice manufacturers from the other's city to their state. And while the Connecticut legislature has funded several programs to encourage business research in such areas as biotechnology and medical devices, these programs are not linked to any well-conceived plans for the transition of aerospace and other manufacturing workers losing jobs into new employment opportunities. And

52. Laura Powers and Ann Markusen, "A Just Transition? Lessons from Defense Worker Adjustment in the 1990s", Economic Policy Institute Technical Paper, 237 (Washington DC, 1999), pp. 3, 25; author interview with Jeff Crosby, union president at GE Lynn, Winter 1998. 53. Wypijewski, "GE Brings Bad Things"; Cowie, Capital Moves; Forrant, "Between a Rock". 
twenty-year Pratt machinists are not going to be employed in financial services companies selling stocks and mutual funds, nor will they be able to make ends meet employed in the low-wage services and retail sectors. At the same time, the IAM and other unions are conspicuously absent from the myriad publicly-funded development agencies established to bring new jobs to Connecticut.

It is no geographical accident that highly skilled jet-engine and aerospace production took place in Connecticut for well over fifty years. Pratt \& Whitney has a long history in the state, developing into leaders in their industry because the fertile skill base along the Connecticut River Valley provided engineering, innovation, and precision production skills. ${ }^{4} 4$ But with ultramodern plants built elsewhere and fewer investments being made in Connecticut, management has "manufactured" the self-fulfilling prophecy that its Connecticut's factories are not productive enough. And as precision metalworking jobs disappear, the skill base cultivated up and down the Connecticut River Valley for over a century is disappearing. ${ }^{55}$

Economist Mary O'Sullivan describes innovation as the process through which productive resources are developed and utilized to generate higher quality and/or lower cost products than had previously been available. ${ }^{56}$ At the enterprise level, strategic decisions are made that determine the performance of the firm and, at the same time, these decisions have effects on the economy as a whole. A work-removal strategy can generate high near-term returns for shareholders, as UTC's stock performance and handsome executive rewards indicates. Should this be the dominant strategy employed by a nation's corporations, the failure to invest in more efficient technologies and skills will eventually lead to a sharp decline in national productive capabilities. Communities that were formerly home to these industries will suffer years of falling living standards and sharp population losses, a trend clearly visible across Connecticut.

At Pratt \& Whitney workers were educated in problem-solving techniques and encouraged to use these skills to continuously improve plant efficiencies, knowing full well that steadily deteriorating job security was likely to follow. To extend their global reach and achieve incomparable shopfloor control, managers have sought to capitalize on two conflicting predilections among workers: the first is the deep-seated fear of the loss of one's job; the second is the desire to contribute one's knowledge and skills in the work environment. It remains the case that the exigencies of global capitalism foster and impose decisions that are made far removed from individual factory floors, completely void of a collective

54. Almeida, "Linking Institutions".

55. Author interviews January and March 200I.

56. Mary O'Sullivan, "The Innovative Enterprise and Corporate Governance", Cambridge Journal of Economics, 24 (2000), pp. 393-416. 
workers' voice. Thus, absent a consistent, concerted, and coordinated international labor voice, global production giants have the capacity to exercise significant bargaining leverage over their worldwide workforce and the power to worsen wages and working conditions for growing numbers of manufacturing workers as we have seen in Connecticut. The best hope for workers and their unions is to forge national and international bonds similar to the reach forged by global corporations. Plant closures and de-industrialization cannot be contested one factory at a time. Of course, this is easier said than done. ${ }^{57}$

In closing, consider remarks by UTC chairman George David before the Council on Foreign Relations. In discussing employment, he stated that Americans "don't want the jobs at the bottom of the economy, we want the jobs at the top, the issue is how to get there". Noting that UTC employed 20I,000 people in 1990, and I48,000 in 2000 - with an announced additional Io per cent cut coming - David urged American corporations to "guard against displacement" and to "establish and adhere to standards of performance and conduct internationally that are fair to employees everywhere". ${ }^{8}$ For Pratt \& Whitney machinist John Cloutier, working every day with the idea in the back of your mind, "How much longer will I have this job?" is extremely stressful. With gallows humor, unionist Ted Durkin gets the last words. "The old ethic that many companies had that their workforces really mattered is long gone. Now, when you leave the plant on Friday not laid off, you feel like you had a great week!" This is hardly the virtuous treatment David espoused before the Council on Foreign Relations.

57. Konzelmann and Forrant, "Creative Work Systems". For a discussion of a local union's corporate strategy, Andrew Jonas, "Investigating the Local-Global paradox: Corporate Strategy, Union Local Autonomy, and Community Action in Chicago", in Andrew Herod (ed.), Organizing the Landscape: Geographical Perspectives on Labor Unionism (Minneapolis, MN, I998), pp. $325-350$.

58. George David, "The Opportunity to Expand Skills and the Knowledge Base", speech before the Council on Foreign Relations, City News Publishing Company Vital Speeches, 66 (n.p., Is March 2000), I4, p. 439. 